Review

\title{
INTEGRATING TRANSNATIONAL MIGRANTS IN VOJVODINA
}

\author{
Doris Wastl-Walter — Irén Gábrity-Molnár — Béla Filep — Zoltán Takács
}

\author{
Project Co-ordinator: \\ Prof. Dr. Doris Wastl-Walter, Professor of Human Geography \\ Vice-rector of the University of Bern; \\ Department of Geography, University of Bern; \\ SWITZERLAND - BERN 3012, Hallerstrasse 12. \\ +410316318016 \\ www.geography.unibe.ch \\ dwastl@giub.unibe.ch
}

Prof. Dr. Irén Gábrity-Molnár

University of Novi Sad; Faculty of Economics;

Scientific Association for Hungarology Research Subotica;

SERBIA - SUBOTICA 24000, Branislava Nusica 2/1.

+381638826589

http://www.mtt.org.rs

gmolnariren@gmail.com

\section{Dr. Béla Filep, Research Fellow}

Department of Geography, University of Bern;

SWITZERLAND—BERN 3012, Hallerstrasse 12.

+410316318016

www.geography.unibe.ch

bfilep@giub.unibe.ch

\section{Zoltán Takács, Research Fellow}

University of Pécs, Faculty of Business and Economics; Ph.D. Program for Regional Policy and Economics; Scientific Association for Hungarology Research Subotica;

SERBIA - SUBOTICA 24000, Branislava Nusica $2 / 1$.

$+38162272845$

http://www.mtt.org.rs

takac.zoltan@gmail.com 


\section{Integrating Transnational Migrants in Vojvodina}

\section{Summary and Preliminary Report on the Research Project “Integrating (Trans-) National Migrants in Transition States (TRANSMIG 2009-2012)"}

The wars in the former Yugoslavia have resulted in thousands of refugees and migrants, who fled and left in several waves to Hungary, to other countries in Europe, to the United States as well as to other parts of the former Yugoslavia, now independent republics. The case of Vojvodina, an autonomous province in Serbia, is a special one: Vojvodina has traditionally been a multiethnic region, and one of those places that have been exposed to a wide range of migration flows with a significant ethnic component (including both emigration and immigration) caused by wars and geopolitical changes. This history makes the region interesting for research on the issue of ex-Yugoslav refugees, which aims at considering the issues raised by the appearance of refugees in different places in Vojvodina, and in parts of Hungary.

In today's Vojvodina, we can detect, as a result of the described migration process, various forms of transnational networks, cross-border lifestyles and cross-border (economic, social and cultural) capital. The everyday activities of people (commuting, studying, business developing, trading - on the both side of the border) as well as their mobility, emotional attachments, and economic relations have brought about a transnational region, which is repeatedly produced and reproduced by people in the course of their daily regionalization (Werlen, 1995). With their everyday practices, transnational lifestyles and cross-border networks, they substantially contribute to the stability of the region (regardless of the physical borders and administrative-territorial characteristics of this region). A crucial aspect of integration is how the people, who migrate, are conceived by state rules and perceived by other people in their daily lives. The status they are accorded to legally or publicly, determines their opportunities and restrictions, their civil rights, their possibilities to make a living, and their integration into the local society. In contrast, the way in which these people deal with their legal and social status and use their (economic, social and cultural) capital and their ability to adjust to the circumstances, perhaps even profiting from their special situation, shapes their living conditions and integration. 
Based on these research problems, we would like to introduce to the readership of "DETUROPE" the research project: "Integrating (Trans-)National Migrants in Transition States (TRANSMIG 2009-2012)", as an interdisciplinary research project coordinated by the University of Bern (Switzerland) in collaboration with the Geographical Research Institute (Budapest, Hungary), the Centre for Regional Studies (Pécs, Hungary) of the Hungarian Academy of Sciences, the Department of Geography, Tourism and Hotel Management (Novi Sad, Serbia) and the Scientific Association for Hungarology Research (Subotica, Serbia). It is a joint SCOPES-project ${ }^{26}$ financed by the Swiss National Science Foundation (SNSF) and the Swiss Agency for Development and Cooperation (SDC).

By investigating the situation in Vojvodina, we are defining three main research objectives:

1. Integration, social cohesion, and attitudes towards refugees and migrants - the project investigates the relationship between different groups and the disposition to conflict in an ethnically mixed environment. Attitudes towards other ethnic groups can take the form of a preference for coexistence, ranging from active collaboration to indifference, or support for conflict, ranging from tensions to ethnic violence. In the last two decades, the ethnic structure in the research area has changed in favour of the Serbs, due to the wave of refugees from Croatia, Bosnia and Herzegovina and Kosovo. Their integration into the new environment and the attitudes, opinions and feelings of the autochthonous inhabitants, both Serbs, Hungarians and other minorities, is crucial to maintaining the social cohesion in such mixed societies.

2. Migrant networks - one of the most important resources for migrants is, as the literature shows (Dahinden 2005; Faist 2000 and 2004; Smith 2003; Brah 1996; Caglar 2006, Leitner and Ehrkamp 2006, Özveren and Faist 2004; Vertovec 2004), their transnational networks. This project focuses not only on the transnational networks and spaces of the migrants, the various ways they are constructed and function, and their diverse offerings, such as knowledge, emotional and financial support, exchange of goods, lodging, and information, but also on their key actors and their social and demographic characteristics. This provides us with a better understanding of the informal and sometimes hidden social structures, which can be a powerful means of survival and integration. We specifically want to investigate how

\footnotetext{
${ }^{26}$ Scientific co-operation between Eastern Europe and Switzerland
} 
these networks contribute to the political and social participation of the newcomers in their new society and how the networks support the newcomers to actively take on their citizenship.

3. Refugee policies (on the level of government, administration and civic associations) - in this project, we examine the different representations on the integration of Hungarian migrants from Vojvodina within Hungarian state discourses and of Serbs from other parts of former Yugoslavia within Vojvodina. Our focus is on governmental discourses and policy, but also on civic associations with various goals. The complex interdisciplinary (sociology and geography), multi-scale (national, regional, local) and multi-locational (Vojvodina, the Serbian-Hungarian border region, Hungary) approach aims at promoting a deeper understanding of tensions and conflicts resulting from the changing/transforming ethnocultural environment and the power relations therein, regardless of whether they come from the same ethnic background or not.

The research is being conducted in and focuses on four research sites:

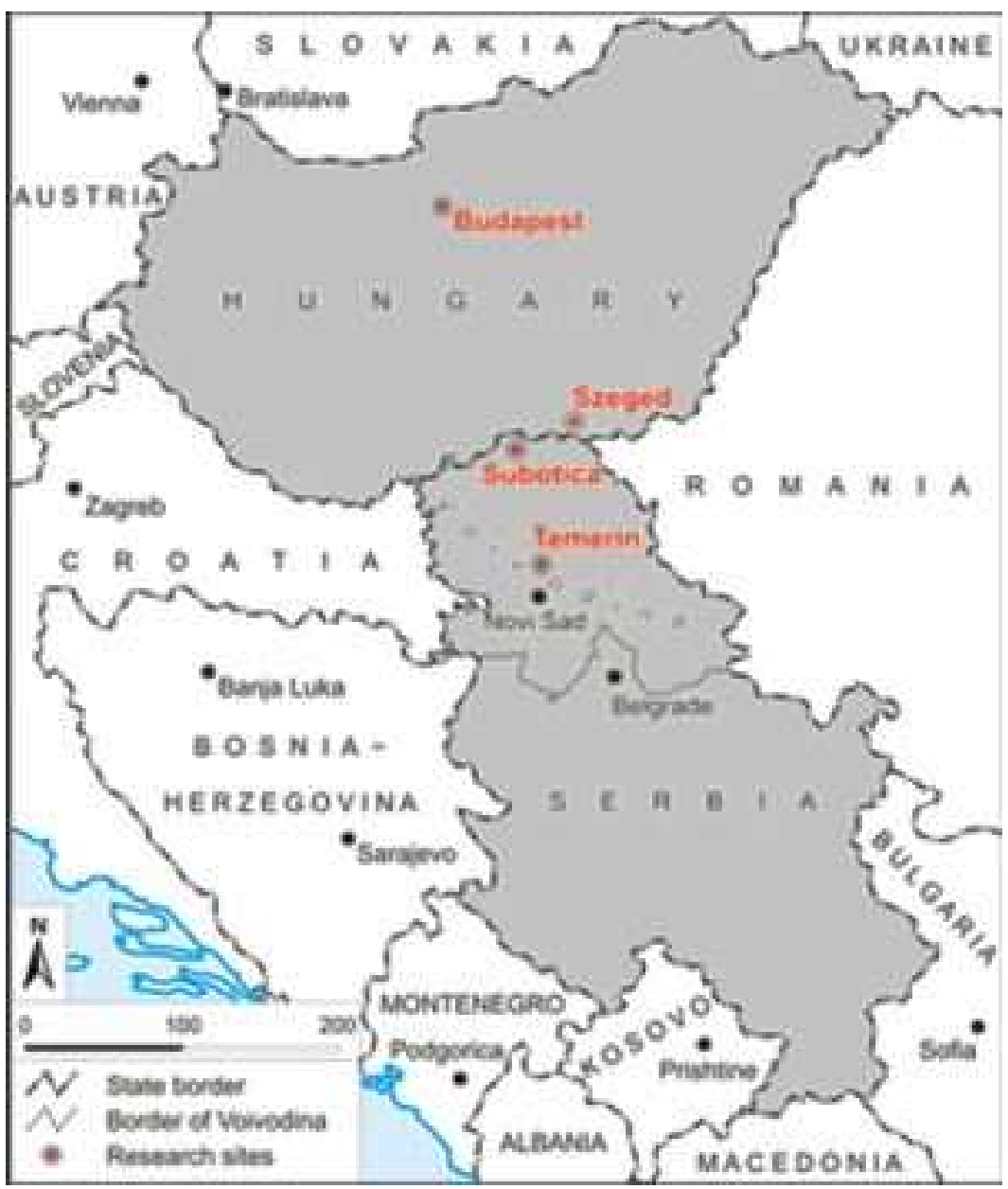


For an in-depth understanding of the migrant/refugee issue, it is necessary to research its different types and aspects in the region. The four selected research sites represent four important settings with regard to our research's focus. In Vojvodina (Serbia), the arrival of refugees brought about conflicts of varying gravity. In the municipality of Temerin, newcomers arrived in a mixed Hungarian-Serbian neighbourhood. Here the tensions manifested in actual violence between the two ethnic groups (Hungarians and Serbs), but conflicts also occurred among the autochthonous and the immigrant Serbs. In Subotica and its surroundings (Palić), Hungarian-Serbian-Croatian coexistence has evolved. This region, which is characterized by Hungarian majority population, is the scene of a more peaceful but not tensionless neighbourhood. The third research site is the Hungarian-Serbian border region with its repeated migrant/refugee flows and strong business and family networks. The last major sites are Szeged and Budapest in Hungary, which have received ethnic Hungarian migrants/refugees.

To meet the objectives of the project in the most comprehensive way, we basically use two approaches: data analysis and fieldwork, combining qualitative and quantitative methods. The emphasis is on the qualitative methods in migration research, mainly in-depth interviews: narrative (semi-structured) interviews with refugees/migrants/commuters, structured interviews with NGOs, entrepreneurs, local political elites, leaders of institutions, focus group interviews, drawing mental maps with stakeholders (e.g. students studying in Hungary, or pupils in multiethnic schools including also children of refugees). Participative observation (e.g. Yugo parties, balls, outdoor activities, exhibitions and other public events), mapping (of ethnical changes), analysis of statistical data and documents are also methods which we apply during this research.

The concrete scientific relevance and added value of the research being conducted: first of all, defining conflict prevention policies (researching contemporary interethnic relations, conflicts, comparing the refugee policies of the countries under research, defining policy recommendations and tangible programs for strengthening interethnic relations and social cohesion in the multiethnic region). Secondly, contributing to a better understanding of the social life and civic associations (by presenting the contemporary mix of coexistence of refugees/migrants/IDPs, different types of neighbourhoods, cultural backgrounds, etc.). Third, 
describing and supporting the creation of links and networks between cross-border institutions represents also a relevant part of the research interest. Finally, the contribution to the economic and societal development of the partner countries plays a significant role in this research. The good-neighbourly relations between Hungary and Serbia are crucial to the possible EU integration of Serbia. Hungary represents Serbia's gate to Europe, as those involved constantly reiterate. Vojvodina plays an important role in these neighbourly relations. Migration represents many problems for local governments and local societies. Our research issue also has economic relevance since research may provide insights into the lack of motivation among the labour force to migrate, an overview of redundant labour force profiles, and information about investment strategies required for business relations.

Furthermore, extending institutional cooperation in order to involve and promote young/junior and female researchers is a central objective of our joint research project, providing benefits such to become involved in international scientific life, to acquire more experience with conference participation, workshops, and presentation techniques in international circles, to establish networks and to work on joint publications.

The empirical work of first and the second year amounts for 200 conducted interviews in the different research sites (81 in Budapest and Szeged, 69 in Subotica and its surroundings, and 40 in Novi Sad and Temerin). The analysis is in process, while there has been continuous discussion between the teams in the framework of project meetings in Budapest, Novi Sad, Szeged, and Subotica in 2010, 2011 and 2012. Results of this research collaboration are crossteam publications, conference papers, and student exchanges.

The research consortium published articles in 5 languages (English, Serbian, Hungarian, German and French). More than 20 scientific papers have been published already in regionrelated journals and in journals relevant for migration studies, more than ten articles in edited books and 2 newspaper reviews.

The project received attention in the media on several occasions. The researchers participated in conferences (generally, organized by international geographical scientific associations) in the following countries: Croatia, Czech Republic, France, Germany, Portugal, USA, Hungary, Serbia, Slovakia, Slovenia and Switzerland. The junior researchers' exchange operated 
between institutions in Switzerland, Hungary and Serbia. On the official website of the project (www.transmig.unibe.ch), research results are continuously publishing.

\section{Preliminary Research Results in a Nutshell}

\section{Focusing on the Serbian-Hungarian border region and Vojvodina}

The different migrant groups (e.g. commuters, students, circulars and seasonal migrants, etc.) in the Serbian-Hungarian border region play a specific role in forming transnational networks and transnational spaces. The everyday activities of the people as well as their mobility, emotional attachments, and economic relations have contributed to the formation of a transnational region, using their material, cultural, social and symbolic capital in various ways; the cross-border contacts in the last century were always present, even in spite of political and historical changes, only their intensity, political charge and tension has been changing. The asymmetries defining the border region have been reflected in different directions, time and with different intensity. In this specially built and constantly reorganizing scope, people who were living their everyday life have tried to use the asymmetries for their benefit, and to improve their possibilities. With their transnational lifestyles and crossborder networks, they substantially contribute to the stability and prosperity of the crossborder region.

These transnational lifestyles have been emerging along the border zone with swaps and (illegal) trades, property purchases and changes of working places in last twenty years. The border region provides a large variety of communication channels and social networks. New transnational styles of life yield possibilities in order to solve the individual and ethnic level challenges first of all of the members of creative class (e.g. entrepreneurs, businessmen, etc.). Emigration and pendulum-like movements of highly qualified youths (30-40 years) have increased from Vojvodina mainly for economic and professional career reasons.

Considering the migration from Vojvodina to Hungary, educational migration is one of the most significant types of migration. During the last twenty years, many Hungarian families in Vojvodina have decided that after finishing primary school in Serbia, their children should pursue their secondary and tertiary education in Hungary. 
The most recent types of migrants along the Serbian-Hungarian border areas are as follows. By status: 1. Settlers (with double citizenship); 2. Circulars and seasonal migrants; 3. Pendulum migrants (from 3 months to 1 year); 4. Students (secondary and tertiary level); 5. Refugees and asylum seekers. By the causes and purposes of migration: 1. Economic migrants, migrant workers; 2. Creative class: entrepreneurs, businessmen, international traders (between the continuum of settlers and circulars); 3. Investors and career builders (brain drain, brain circulation); 4. Family unification or reunification (marriage as family formation and for instance retirement movement as family reunification); 5. Applications for Hungarian citizenship; 6. Recreational migrant-tourists.

We emphasize the fact that migrations always happen in certain spatial/social configurations and that migrants (i.e. their identities) are influenced by economic, political and cultural structures of the given (new) spatial and social context. The interviewee responses in this research reflect to the greatest extent the subjective dimension of identity construction (considering the case of refugees in Vojvodina). The analysis of interviewee responses indicates that war circumstances and exile have to a great extent affected the strengthening of ethnic identity, which had not been too prominent in a previous period of life. Interviewee responses have also indicated that, despite certain variations (especially in the relationship towards other nations and ethnic groups), ethnic identity represents a very important dimension of their cultural identity. War experience and exile have contributed to the development of national awareness and identity.

The socio-cultural dynamics of the new setting also affect the stability of identity and a sense of belonging in a special way. The relationships in the new social setting have been represented through the interviewees' answers to the questions concerning the reasons for coming to Temerin and how the local population accepted them. The answers indicate that these experiences are mainly positive. As refugees, their position was facilitated by the fact that many of them had relatives, friends or acquaintances here. Yet, there were also those who listed economic reasons, i.e. employment, as the main reason for coming to Temerin. The fact that (with more or less problems) they managed to become Serbian citizens contributed to that awareness and feeling of symbolic identification, belonging to a state and a nation, i.e. a kind of reterritorialization of their identity.

Bern-Subotica, $15^{\text {th }}$ of December, 2012.

\section{Integrating Transnational Migrants in Vojvodina}

Publications, conference presentations and Dissemination (2010-2012) 


\section{Scientific Association for Hungarology Research Subotica, Serbia}

\section{Publications}

1. Gábrity Molnár Irén. A menekültek betelepülésével a Vajdaság már nem ugyanaz (The refugees in Vojvodina is not the same) 2010 In: Aracs, A délvidéki magyarság közéleti folyóirata Serbia. Ed: Mák Ferenc, X/1. No. April 15. 2010 Aracs Társadalmi Szervezet (Aracs Social Organization) Subotica, Serbia. pp. 54-58. www.aracs.org.rs/afolyoirat/folyoirat-arcivum/doc.../36-aracs-2010-1

2. Ricz András, Gábrity Molnár Irén: A Vajdaság régiókapcsolatai a Dél-Alföldel (Vojvodina and southern Great Plains region relations) 2010 In: Régió a hármashatár mentén, DélAlföldi Régió; Ed.: Soós Edit and Fejes Zsuzsanna University Szeged, State Faculty of Law, Hungary pp. 76-93.

3. Gábrity Molnár Irén: A vajdasági magyarok emigrációs motívumai (The motives of emigration of Hungarians in Vojvodina) 2010 In: Vándorló kisebbségek. Etnikai migrációs folyamatok Közép-Európában történeti és jelenkori metszetben. Ed.: Kupa László. University Pécs - Bookmaster Kft. Pecs Hungary. pp. 117-126. http://www.sinesymposium.hu/konyvek/vandorlo_kisebbsegek.html

4. Kincses Áron, Takács Zoltán: Szerb állampolgárok Magyarországon (Serbian Citizens in Hungary) 2010. In: Területi Statisztika. 13. (50.) évf. 2. sz. 2010. ISSN: 0018-7828. Ed:

Kovács Tibor Hungarian Central Statistical Office, Hungary. pp. 182-197.

http://portal.ksh.hu/pls/ksh/docs/hun/xftp/terstat/2010/02/kincses_takacs.pdf

5. Kincses Áron, Takács Zoltán: Schengent megelözö szerb népességmozgás és a szomszédos Magyarország szerepe (Schengen before Serb population movements and the role of neighboring Hungary) 2010. In: Deturope. The Central European Journal of regional development and tourism. Vol 2. Issue 1. ISSN 1821-2506 online Czech Republic-HungarySerbia. pp. 66-82.

http://home.zf.jcu.cz/public/projects/cejrdt/img/upload/volumes_26413863.pdf

6. Zoltan Takač, Aron Kinčes: Migracija stanovništva iz Republike Srbije u susednu Mađarsku u razdoblju pre Šengenskog sporazuma. 2010. In: Anali Ekonomskog fakulteta u Subotici (The Annals of the Faculty of Economics Subotica). Vol 46. Issue 24. ISSN: 03502120. University of Novi Sad Faculty of Economics Subotica, Serbia. pp. 69-82.

7. Gábrity Molnár Irén: Az interetnikus konfliktusokról Vajdaságban 10 évvel a délszláv háború után (The inter-ethnic conflict in Vojvodina, 10 years after the Balkan wars) 2011. In: Görbe háttal, Interetnikus konfliktusok Közép-Európában a múltban és a jelenben. Pécsi Tudományegyetem Bölcsészettudományi kar, University of Pecs, and Virágmandula Kft. Pécs, Hungary. pp. 162-176

8. Irén Gábrity Molnár: The motives for Emigration of Hungarians in Vojvodina. 2011. In: Minderheitendasein in Mittel- und Osteuropa - interdisziplinär betrachtet, Socialia, Studienreihe Soziologische Forschungsergebnisse, Band ISSN 1435-6651. Ed: Zsuzsanna Gerner László Kupa (Hrsg.) Verlag Dr. Kovač, Hamburg, Deuchland. pp. 103-114 9. Gábrity Molnár Irén: Kapcsolatok a szerb-magyar határmentén (Relations with SerbianHungarian border)2011. In: Magyar Szó, Magánvélemény, 2011. October 1. Ed: Varjú Márta Forum, Novi Sad. Serbia. p. 12.

10. Gábrity Molnár Irén: Vajdaság népességének háború okozta attitüdjei. (Assembly of the population of war-related attitudes.). 2011. In: Magyarságkutatás Vajdaságban (Research of Hungarians in Vojvodina). Ed. Gábrity Molnár Irén Scientific Association for Hungarology Research Subotica, Serbia. pp. 34-87. 
11. Takács Zoltán: Felsőoktatási intézménykapcsolatok egy határral szabdalt régióban (Networks of Higher Education Institutions in a Region Divided by Borders). 2011. In: Magyarságkutatás Vajdaságban (Research of Hungarians in Vojvodina). Ed. Gábrity Molnár Irén Scientific Association for Hungarology Research Subotica, Serbia. pp. 128-150. 12. Szügyi Éva, Takács Zoltán: Menni vagy maradni? Esélylatolgatás szerbiai és magyarországi diplomával a Vajdaságban. (To Leave or Stay? The Options for Hungarians in Voivodina with Serbian or Hungarian Degrees). 2011. In: Évkönyv 2011. Regionális Politika és Gazdaságtan Doktori Iskola (Annual 2011 Ph.D. Programme of Regional Politics and Economics at the University of Pécs, Hungary). Ed. Páger Balázs. University of Pécs, Hungary. pp. 283-301.

13. Zoltan Takacs, Eszter Gábrity: Development of Higher Education Networking in Multiethnic Border Region of North Vojvodina. 2011. In: Glasnik UP ZRS, Letnik Vol. 16, 2011, No. 7. ISSN: 2232-349X. Koper, Slovenia. pp. 103-104. http://www.zrs.upr.si/media/uploads/files/Glasnik\%20\%C5\%A1t\%20\%207-2011\%20\%20arhiv.pdf

14. Doris Wastl-Walter, Milan Cvetanović, Ágness Erőss, Béla Filep, Eszter Gábrity, Irén Gábrity-Molnár, Saša Kicošev, Károly Kocsis, Imre Nagy, Katalin Rácz, Zoltán Takács, Patrik Tátrai, Monika M. Váradi: Transnationale Migration und grenzüberschhreitende Mobilit als Einflussgrösen der Regionalentwicklung im ungarisch-serbischen Grenzraum. 2011. In: Grazer Schriften der Geographie und Raumforschung, Band 46/2011. NachhaltigkeitRegionalentwicklung-Turismus. Ed. Suzanne Janschitz, Gerhard Karl Lieb. Institut für Geographie und Raumforschung, Universitet Garz, Switzerland. pp. 247-262. www.unigraz.at/geowww

15. Szügyi Éva, Takács Zoltán: Migrációs karrierkövetési vizsgálatok a vajdasági magyar fiatal közgazdászok és mérnökök körében (Migration Carrier-study of Vojvodina Hungarian Young Economists and Engineers) 2011. In: Deturope. The Central European Journal of Regional Development and Tourism. Vol. 3 Issue 3 ISSN: 1821-2506. online Czech RepublicHungary-Serbia. pp. 66-84 http://www.deturope.eu/img/upload/volumes_45968606.pdf 16. Áron Kincses, Zoltán Takács: Characteristics of Serbian-Hungarian International Migration before Schengen. 2012. In: Statisztikai Szemle. Vol. 90. No. 15. (Hungarian Statistical Review, Special No. 15) Budapest, Hungary. pp. 98-108. http://www.ksh.hu/statszemle_archive/2012/2012_K15/2012_K15_096.pdf 17. Takács Zoltán: Regionális és határon átívelö felsőoktatási intézménykapcsolatok és együttmüködések Észak-Vajdaságban (Regional and Cross-border Cooperation in Higher Education of North-Vojvodina). 2012. In: Educatio (Quarerly Rewiew of Social Sciences Focused on Education), HU ISSN 1419-8827, No. I. 2012, Hungary. Ed: Kozma Tamás. Budapest, Hungary. pp. 104-122. http://www.edu-online.eu/hu/educatio.php 18. Gábrity Molnár Irén: A szerb-magyar határon átívelö migrációs életvitel (The SerbianHungarian cross-border migratory lifestyle). 2012. In: Létünk 2012/4. 314.7(497.11+439) Bence Erika (ed.) ETO: 32+008+81+82. ISSN YU 0350-4158. COBISS.SR-ID 4664578. Forum Könyvkiadó, Újvidék / Novi Sad, Serbia. pp. 56-69

19. Gábrity Eszter: The intertwining of linguistic identity and ideology among Hungarian minority commuters from Vojvodina to Hungary. 2012. In: Jezikoslovlje 13.2 (2012) Osijek, Croatia. pp. 652-643

20. Gábrity Eszter: 'But ever since so to say I have taken over the proper words ... so to say I have no problems': language ideologies of Vojvodina Hungarian migrants and commuters from Serbia to Hungary. 2012. In: Zbornik za jezike i književnosti Filozofskog fakulteta u Novom Sadu (The Journal for Languages and Literatures of The Faculty of Philosophy in Novi Sad). Novi Sad, Serbia 
21. Gábrity Eszter: „Ahol nem tudnak magyarul, ott én önként átváltok szerbre,, Vajdasági magyar migránsok és ingázók államnyelvvel kapcsolatos nyelvi ideológiái. 2012. Conference proceedings: $4^{\text {th }} \mathrm{PhD}$ Conference Budapest, Hungary.

22. Дорис, Вастл-Валтер - Моника, Варади - Золтан, Такач: Транснащионалне миграџије и прекогранична мобилност у пограничном региону Србија-Мађарска (Transnational Migration and Cross-border Mobility in the Serbian-Hungarian Border Region). 2013. In: Anali Ekonomskog Fakulteta u Subotici. ISSN: 0350-2120. Subotica, Serbia.

23. Takács Zoltán, Kincses Áron: A Magyarországra érkező külföldi hallgatók területi jellegzetességei (The foreign students coming to Hungary spatial characteristics). 2013. In: Területi Statisztika Budapest, Hungary

\section{Lectures and conference presentations}

1. Gábrity Eszter: TransMig - A vajdasági magyar migránsok és határon átívelő ingázók nyelvi helyzete (Hungarian immigrants and linguistic situation of cross-border commuters) 2011. University Szeged, Hungary, 6th Faculty PhD Conference Szeged, 1 June 2011

2. Gábrity Eszter: The linguistic identity of Vojvodina Hungarians. 2011. Conference on concepts and consequences of multilingualism in Europe 3, Pecs-Osijek, 8-11 June 2011 3. Gábrity Eszter: Multilingual practices among Hungarian minorities in Vojvodina Identity in transition? 2011. LINEE (Languages in a Network of European Excellence) Training Institute, Prague, 20-24 June 2011

4. Takács Zoltán: Student Mobility or Emigration Flow? The Case of Commuting students from Serbia to Hungary 2011. BRIT XI, Genf, Switzerland, 6-9th of September 2011.

5. Takács Zoltán, Gábrity Eszter: Vojvodina in focus of migration and identity changes. 2011.

Workshop of the Working Group on Central Europe in conjunction with the 4th Conference of the Adriatic Forum, Zadar, Croatia, 14-15th of September, 2011.

6. Takács Zoltán, Gábrity Eszter: Development of Higher Education Networking in Multiethnic Border Region of North Vojvodina. 2011. (Re)integration and development issues in multicultural and border regions, IGU, Portorose, 22-24th of September, 2011.

7. Gábrity Molnár Irén: Kapcsolatok a Szerb-Magyar határ két oldalán lévő területek és lakosok között (Relations with Serbian-Hungarian border area and residents on both sides).

2011. Scientific conference: "Határon innen és határon túl - Cross here and beyond". Location: Department of Public Law, Faculty of Political Science Department. Szeged, Hungary, 2011. October 21.

8. Takács Zoltán: Határon átívelö felsőoktatási kapcsolatok (Cross-border Cooperation in Higher Education). 2011. The $11^{\text {th }}$ Conference of Hungarian Regional Science Association, Komarno, Slovakia, 25-26th of November, 2011.

9. Takács Zoltán: Regionális és határon átivelö felsőoktatási intézménykapcsolatok és együttmüködések Észak-Vajdaságban (Regional and Cross-border Cooperation in Higher Education of North-Vojvodina). 2011. Annual Conference of Hungarian Sociological Association, Miskolc, 11-13th of November, 2011.

10. Gábrity Molnár Irén: A vajdasági magyarok szerepe és motívumai a szerb-magyar határmenti kapcsolatépitésben (The role of ethnic Hungarians in Vojvodina and the SerbianHungarian motifs border networking). 2011. Scientific conference: Az 1944-45-ös délvidéki magyar tragédia, a magyar-szerb történelmi kapcsolatok tükrében (1944-45 Southern Hungarian tragedy of the Hungarian-Serbian view of historical relations.). Location: Hungarian Academy of Sciences. Budapest. 25th November 2011.

11. Gábrity Molnár Irén: Vajdaság népességének háború okozta attitüdjei (Assembly of the population of war-related attitudes) 2011. Scientific conference: "20 years of research in 
minority hosts". Organization: Scientific Association for Hungarology Research, Subotica, Serbia. Location: Hungarian Language Teacher Training Faculty of Subotica, $17^{\text {th }}$ December 2011.

12. Takács Zoltán: Felsőoktatási intézménykapcsolatok egy határral szabdalt régióban (Networks of Higher Education Institutions in a Region Divided by Borders). 2011. Scientific conference: "20 years of research in minority hosts". Organization: Scientific Association for Hungarology Research, Subotica, Serbia. Location: Hungarian Language Teacher Training Faculty of Subotica, $17^{\text {th }}$ December 2011.

13. Zoltan Takac, Andreas Winkler: Regional policy and regional disparities

Institutionalisation of spatial development in Serbia with focus on the Autonomous Province of Vojvodina. 2012. 32nd International Geographical Congress (IGC), 26-30th of August, 2012. Bern, Switzerland.

14. Gábrity Molnár Irén: Új migrációs típusok és lakossági kapcsolatok a szerb-magyar határmentén

(New types of migration and public relations of the Serbian-Hungarian border). 2012.

Scientific conference: Regionális együttmüködés lehetőségei (Vajdaság - Dél-Alföld).

Organization: Szabadkai Regionális Tudományi Társaság, MRTT Dél-alföldi tagozata, MTA Szegedi Területi Bizottsága Gazdaságtudományi Szakbizottsága. Location: SZAB Székháza Szeged. $25^{\text {th }}$ October 2012.

15. Gábrity Molnár Irén: A szerb-magyar határon átívelő migrációs életvitel (The SerbianHungarian cross-border migratory lifestyle). 2012. Scientific conference:

Társadalomtudományi, kultúratörténeti, kulturális antropológiai kutatások a XXI. század elején (Európai és regionális mozgások). Organization: Létünk folyóirat. Location: Forum, Újvidék/ Novi Sad, Serbia. $27^{\text {th }}$ October 2012.

16. Eszter Gabrity, Zoltan Takac: Language divided by border. Border and language consciousness among Hungarian migrants and labor migrants between the Serbian-Hungarian borders. 2012. The "Borders and Borderlands: Today's Challenges and Tomorrow's Prospects", the 2012. Organization: European Association of Borderland Studies. 12th to $15^{\text {th }}$ September 2012. Leipzig, Germany.

17. Gábrity Eszter: „Ahol nem tudnak magyarul, ott én önként átváltok szerbre,, Vajdasági magyar migránsok és ingázók államnyelvvel kapcsolatos nyelvi ideológiái (Vojvodina Hungarian migrants and commuters state language learners' linguistic ideologies) 2012. $4^{\text {th }}$ PhD Conference Budapest, 15 ${ }^{\text {th }}$ November 2012.

18. Gábrity Eszter, Takács Zoltán: Serbian and Hungarian migrants' language ideologies in Vojvodina. 2012. Konteksti Novi Sad, Serbia. 1 December, 2012

\section{Dissemination:}

1. October 2011. Gábrity Molnár Irén: Kapcsolatok a szerb-magyar határ mentén, In: Magyar Szó, Vélemény, Forum, Újvidék. p.12.

3. October 2011. Subotica's staff informed the press about the project's current job, A report with Irén Gábrity Molnár in air on Pannon TV. Broadcast address „Híradó”. She was asked about the project and the emigrants in Vojvodina.

5. October 2011. A report with Doris Wastl-Walter, Monika Mária Váradi and Irén Gábrity Molnár in Magyar Szó "Közélet" (Hungarian language - regional daily newspaper): Az identitásváltás nyomában, Nemzetközi projektum keretében modellezik a 
szerb-magyar határ menti régiók migrációs szokásait. p. 5. http://magyarszo.com/fex.page:2011-10-05_Az_identitasvaltas_nyomaban

5. October 2011. A report with Doris Wastl-Walter, Monika Mária Váradi and Irén Gábrity Molnár in online Magyar Szó (Serbian language): Tragom izmene identiteta. http://www.magyarszo.com/fex.page:2011-10-05_Tragom_izmene_identiteta.xhtml

6. October 2011. Subotica's staff informed the press about the project's current job, A report with Doris Wastl-Walter, Monika Mária Váradi and Iren Gabrity Molnar in air on Pannon TV. The title of the show is „Közel-kép”. She was asked about the project and the emigrants abroad in Vojvodina.

25. Marc 2012. A report with Zoltan Takacs in Dnevnik (Serbian language - regional daily newspaper): Мађарски пасош као улазница за Европу. PRESS CLIPPING: DNEVNIK: Prof. Iren G. Molnár. and Prof. Saša Kicošev were giving interviews about the research conducted in framework of TRANSMIG. In Serbian: Integracija migranata na relaciji Vojvodina-Mađarska. Još uvek se mladi ne vraćaju (In English: Integrating migrants on relation Vojvodina-Hungary. The Young People Still Do Not Return). http://issuu.com/dnvdvp/docs/dnevnik250312 [2] (DNEVNIK, 25th of March 2012. pp. 6-7)

7. November 2012. A report with Irén Gábrity Molnár in „Hét Nap” Szabadka, Serbia: Magyarország egyre nyitottabb p. 12.

2012. december 3. 12:23. MTI. Hungary. A gazdasági migráció vált meghatározóvá a Vajdaságban, Délvidékröl érkezettek elsősorban Szegeden települtek le.

3. December 2012. Vajd.ma. Serbia. http://www.vajma.info/cikk/vajdasag/14494/

3. December 2012. Hungary. http://www.vajdasaghirek.com/index.php/idjaras/12459transmig-projektzaro-konferencia-szegedszabadka

2012. december 03., hétfö 13:09 | Hírek.sk | Forrás: MTI. Hungary. Sokan kétlaki életet élnek a Vajdaságban

http://www.hirek.sk/kulfold/20121203114220/Sokan-ketlaki-eletet-elnek-a-Vajdasagban.html

2012. december 03., hétfő Hungary. http://vajdasag.eu/v20121203szeged

3. December 2012. Városi TV Szeged. Hungary. MTI.

http://vtvszeged.hu/hun/s_!news/i_34/i_ 7800

4. December 2012, kedd. Pannon rtv_Szabadka, Serbia. Híradó (in Hungarian) https://www.youtube.com/watch?v=4ezC1qTx9Gs

Magyar Szó, Serbia (in Hungarian): http://magyarszo.com/fex.page:2012-12-

04_A_gazdasagi_migracio_valt_meghatarozova_Vajdasagban.xhtml

4. December 2012. [23:28] Vajd.ma (online Serbia). Tanácskozás Szabadkán: határon átnyúló kapcsolatok és a migránsok életmódja. 
http://www.vajma.info/cikk/tudomany/3691/Tanacskozas-Szabadkan-hataron-atnyulokapcsolatok-es-a-migransok-eletmodja.html

04. December 2012. Régió Rádió. Hungary. http://hangtar.radio.hu/mr6szeged\#!\#2012-12-04 Hungary. http://galamus.hu/index.php?option=com_content\&view=article\&id=178199:agazdasagi-migracio-valt-meghatarozova-a-vajdasagban\&catid=76:hazai-vonatkozasu$\underline{\text { hirek\&Itemid=113 }}$

04/12/2012 - 14:55 Yu eco rtv (in Serbian) Sandra Iršević, Naučni skup o migracijama. http://www.yueco.rs/vest/dru-tvo/nau-ni-skup-o-migracijama

05. December 2012. Magyar Szó. Serbia. http://magyarszo.com/fex.page:2012-1205_Letelepedes_helyett_ingazast.xhtml http://www.magyarszo.com/fex.page:2012-12-05_Cirkulisanje_umesto_nastanjivanja.xhtml (Vesti na srpskom - Hírek szerbül)

10. December 2012. Pannon RTV Szabadka/Subotica, Serbia. Közel-kép - 2012.12.10. Az elvándorlás okai - migráció zárókonferencia. http://pannonrtv.com/web/?p=4351 